\title{
Specificity of Multiculturalism in Switzerland
}

\author{
Prof. Dr. mult. Miroslaw Matyja Dr. h.c. \\ Logos International University / USA \\ Polish University Abroad in London; \\ Selinus University in Bologna/Italy; \\ Indian Management School and Research Centre in Mumbai/India \\ m.matyja@sunrise.ch
}

\begin{abstract}
Switzerland consists of different regions, cultures and languages. The minorities in Switzerland are in the first place ethno-linguistic minorities, whose are unified by a common language. Therefore, since the foundation of the Confederation in 1848 the Helvetic state has been considered a multilingual country. The confederation and cantons are obliged to protect linguistic minorities. The grounds of the Swiss social structure, with traditional multiculturalism and four national languages are two principles: language freedom (Sprachenfreiheit) and territoriality (Territorialitätsprinzip). Switzerland has no official state religion. Predominant religion is Christianity, the largest religious minorities is established by Islam. The largest Christian denominations are Catholic Church (37.7\%) and Swiss Reformed Church (25.5\%). The influx of new cultural minorities to Switzerland began after the Second World War and was directly connected with economic migration, with the large influx of gastarbeiters from southern European countries and refugees from the Third World and from the former Yugoslavia.International law includes the protection of national, yet not cultural minorities. In Switzerland the protection of national minorities is also based on international standards.
\end{abstract}

Keywords. Switzerland, Swiss minorities, direct democracy, cultural minorities, Swiss integration policy

\section{Introduction}

Multicultural Switzerland has been ethnically diverse from the beginnings of its statehood. It has existed as a state in its present form since the adoption of the Swiss Federal Constitution in 1848, when Switzerland transformed from a poor nation of farmers into a society with unprecedented prosperity and political stability. Bold systemic and institutional solutions based on direct democracy, favourable economic situation and specific historical circumstances allowed Switzerland to manage any internal and external conflicts, notwithstanding it is overflowing with a mosaic of national, linguistic and religious minorities. 
The aim of this article is to present the complex issue of multiculturalism in Alpine Republic. The article analyzes a diverse and multicultural Swiss society in the political, socio-cultural and sociomoral aspects. The additional value of this text is the analysis of the dependence of the status of cultural minorities in the Helvetic state on the instruments of direct democracy.

\section{Multicultural dispersion}

The establishment of the Swiss Confederation was not based on one language and one culture, as it is in most European countries. The modern multicultural Switzerland is a combination of myriad different components into a unity, primarily of a political nature, hence the Swiss are considered to form a "nation of will" (German Willensnation). Over the centuries, Switzerland was struggling with numerous intercultural problems, religion conflicts and language tensions. The beginnings of the country connect with the union of three German-speaking cantons: Uri, Schwyz and Unterwalden, which concluded the Eternal Alliance in 1291, on Rütli hill. First Confederation (1798) was a mainly Germanspeaking state, which makes the domination of German language and Germanic culture so visible nowadays. Along with the development of the Confederation other cantons joined it; not only German, but also French and Italian.

The Swiss society became more and more diversified and multifaceted. At the time of so called Helvetic Republic (1798-1803), previous dependent French and Italian-speaking territories gained a status of equal cantons, thus the French and Italian languages gained the same position as the German language. Consqeuently, the constitution of 1848 recognized those three languages as national. It was the next stage of Swiss transformation into a multilingual and multicultural country. The Swiss national identity began to crystallize only in the first half of the twentieth century as a response to internal assimilation processes and external threats from neighboring countries - European powers competing during the First World War. The interwar period strengthened the Swiss consciousness regarding cultural diversity. An important role played the conflict with Italy, which claimed the Italian-speaking canton of Ticino and the Romanesque areas of the canton of Grisons. The national referendum and a partial modification of the 1938 Constitution were also of great importance, as the Romansh language became the national language of Switzerland. In 1999 the referendum and new constitutional provision enhanced the status of Romansh as one of the official languages, and guaranteed its preservation.

At present, there are four language groups in Switzerland (German, French, Italian and Romansh). Due to the significant disproportions in the number of users of particular languages, the cantons of two smaller language regions (Italian and Romansh) receive additional funds supporting education and culture. This was intended to maintain Swiss multiculturalism. Notwithstanding, the budget distribution in this matter is disproportionately beneficial for the smaller culture groups (Zbinden, 2006). Due to the specificity and historical development of Switzerland the hallmark of various areas - including 
intellectual, artistic and scientific - is far-reaching decentralization and regionalization. Therefore, the cantons and large cities, such as Base, Geneva or Zurich, were financially responsible for cultural projects. It created the differences in the scope and pace of development of various cultural phenomenons in individual regions of the country (Wojtowicz, 1976: 251).

The initiatives supporting Swiss multiculturalism aim to maintain the harmony between particular cultures and prevent the isolation of different national, linguistic and religious groups. However, each region finds its own way to deal with the difficulties (Porębski, 2009: 165). As it was mentioned before, the problematic issue of the Rhateo-Romansh Swiss is its small size. Additionaly, the Romansh in this region is splitted into several dialects. The Italian-speaking area (Ticino) is economically and structurally dependent on the Swiss German area. They did not have a university there until 1996, which made the young people educate outside their region. The French-speaking part of the Switzerland, although it does not diverse as much in dialects and is fulfilled with francophonie cultural and linguistic organizations, encounters cultural barrier and isolation, particularly with the neighboring Germanspeaking group. The main issue in German-speaking part of Switzerland — which has the biggest territory, population and economic power - is communication with other linguistic groups of the state, as well as the substantial number of dialects. The Standard German (Hochdeutsch) is rarely used by the German-speaking Swiss. In writing, they generally use so-called: Swiss-German language, however they speak Schwyzerdütsch, which is divided into many diverse dialects.

While speaking about Swiss multiculturalism, the relation between Swiss and immigrants, the number of who is still increasing, should also be considered. The attitude towards strangers is dual: on the one hand one can observe the traditional Swiss openness, on the other hand - there is a rigid distinction between citizens of Switzerland and foreigners. It might even be spoken about so-called parallel society. This causes numerous problems, including integration difficulties of foreigners, or the fear of the loss of national identity in Swiss society.

The researches of Swiss culture draw attention to the factors which foster the effective management of multiculturalism, primarily to political, economic, and geographical issues. One should mention the Switzerland's distinctive geopolitical location and its relations with neighoboring countries, the historical development of the Confederation, additionally the migration policy related with waves of political and economic immigration. Multiculturalism of Switzerland is mainly the result of specific geographical location at the crossroads of strong cultural influences from Germany, France and Italy. To this today, Switzerland was able to effectively manage this diversity by adjusting institutional solutions, and benign economic environment.

When it comes to the forms of multiculturalism management, it should be noted that the unique political organization of Switzerland, allowed its preservation in harmony, regardless of immense religious and linguistic diversity. Four decisive factors need to be distinguished: constitution, where 
diversity is a certainly important matter, federalism capable of minimizing the conflicts, federal council, and representative direct democracy (Porębski, 2009: 165).

The grounds of the Swiss social structure, with traditional multiculturalism and four national languages are two principles: language freedom (Sprachenfreiheit) and territoriality (Territorialitätsprinzip) (Porębski, 2009: 163). The first one implies everyone's right to use their mother tongue. The second refers to the communication between inhabitants and authorities (one of the four Swiss national languages has to be used - the language of the majority on the particular territory), thereby the territoriality principle prevails over the language freedom. Political and administrative units that define the functioning of the territoriality are cantons and municipalities, not the state as a whole.

The model of Swiss multiculturalism formed in the frst half of the twentieth century, the regional rooting of plurilingualism based on the deep tradition of coexistence of various national and language groups, is currently undergoing a serious test. It is affected and significantly changed by globalization. Traditional ethnic Swiss communities encounter many difficulties in maintaining the Helvetic model, which was developed and verified in the past.

The Swiss cultural policy has its own laws. In comparison, with other European countries, it does not have one common strategy of operations in this area. It is mainly the responsibility of the cantonal and city authorities, while the state authorities only perform coordination function.

\section{Linguistic minorities}

Swiss constitution determines two fundamental principles of language policy towards linguistic minorities. The first one defines the right of linguistic minorities to use their own language, the second calls for the protection of minority national languages. It is ensured by the Swiss language policy, which attaches high importance to protection of Italian and Romansh language in cantons of Grizons and Ticino (Pedretti, 2000: 269).

Constitution revised in 1874 enshrined German, French and Italian languages as the national languages, which guaranteed their protection on both general and cantonal level (Haller, 2005: 17-20). The linguistic freedom recognized as a fundamental right is guaranteed in Article 18 of the Constitution, including dialects and written language. The Article guarantees that every citizen has the right to use their own language. However, Article 18 may come into conflict with the territoriality principle, which forbids the state from making any changes within the constellation of languages by linguistic policy means. The exception is the measures taken by the state to ensure the stabilization and protection of minority national languages in certain regions.

The most important constitutional principle regarding linguistic policy in Switzerland is undoubtedly Article 70, commonly known as the "language article" (Sprachenartikel). Paragraph 3 Article 70 emphasizes the role of cooperation between linguistic communities, which should be 
encouraged by both the federal and cantonal authorities. State and cantonal institution should act pursuant to the provisions of Article 2 of Swiss Constitution, accordring to which federation and cantons are obliged to preserve and strengthen the cultural unity of the Swiss Confederation.

To conclude, Article 70 is a fundamental part of Swiss linguistic policy, as it provides basis for further provisions regarding supporting and protection of linguistic minorities.

Article 2 affects other provisions of the constitution, and depends only to non-binding international law. Whereas Article 8 paragraph 2 establishes equality before the law, including the use of language. Constitutional principles of Article 70 have therefore strong legal grounds from Article 2, Article 8 paragraph 2, and Article 18.

Switzerland consists of different regions, cultures and languages. The minorities in Switzerland are in the first place ethno-linguistic minorities, whose are unified by a common language. Therefore, since the foundation of the Confederation in 1848 the Helvetic state has been considered a multilingual country.

Each language region broadcasts its own radio programs and publishes numerous newspapers. About two-thirds of the Swiss speaks Swiss-German (Schwytzertütsch). The French language spoken in Switzerland does not differ much from the language used in France. The purest form of French occurs in the Neuchâtel canton. There are some differences between the dialect found in the Italian-language Ticino and the standard Italian language, however they are minor. Most of the citizens of the country know more than one language - the second national language, or more often in recent years, the English language. Historical conditionings and the central location of Switzerland between the three significant cultures of Europe (German linguistic area, France and Italy) led to linguistic and cultural diversity of Switzerland. The culture of the different parts of the country is still being shaped by neighboring countries, which use a given national language.

The fourth official language is the Romansh language, derived from Latin, used by less than $0.5 \%$ of the Swiss, mainly in Grisons. It constitutes a linguistic relic — the Rhaetian is one of the local dialects, which usually occur in one particular mountain valley. They are being constantly raplaced by German language, therefore are threatened with extinction. Romansh has been recognized as one of four "national languages" by the Swiss Federal Constitution since 1938.

Multilingualism is an integral part of Switzerland's identity which secures acknowledgment of the national minorities in this country. It is guaranteed by the constitution. The confederation and cantons are obliged to protect linguistic minorities (Richter, 2005: 407-1006).

Contrary to Belgium, linguistic regions in Switzerland do not have political structures and the language border is not equivalent to the cantonal border. It explains, to a certain extent, peaceful coexistence of linguistic minorities (Bakic, 2010).

Table 1 Swiss population - Languages spoken in Switzerland in $2018(\%)$ 


\begin{tabular}{|l|l|}
\hline Language & $\%$ \\
\hline German & 63.0 \\
\hline French & 22.7 \\
\hline Italian & 8.1 \\
\hline Romansh & 0.4 \\
\hline Spanish & 2.2 \\
\hline Serbo-Croatian & 3.0 \\
\hline Portuguese & 3.7 \\
\hline English & 4.9 \\
\hline Albanian & 2.4 \\
\hline Other & 9.1 \\
\hline
\end{tabular}

Source: Federal Statistical Office:

https://www.bfs.admin.ch/bfs/de/home/statistiken/bevoelkerung/sprachenreligionen/sprachen.assetdetail.2244919.html (10/01/2020)

The above Table indicates that besides the traditionally dominant languages used by Swiss society (German, French, Italian and Romansh), there are other significant languages that emerged in Switzerland as a result of the immigration process.

The foreigners make up over $20 \%$ of the Swiss population, without taking account of foreigners who are waiting for asylum and have the temporary stay permits ${ }^{1}$. Switzerland is a melting pot of more than 190 nationalities. The largest groups are Italians, followed by former Yugoslavians, Portuguese, German, Spanish, Turkish and French. The incoming foreigners are refugees seeking shelter, families of already settled immigrants, job and asylum seekers and students. Immigration to the Helvetia was shaped in history and continues to be shaped depending on the political situation in the world. For example, Hungarians arrived after 1956, Czechs and Slovaks after 1968, and Poles during martial law in the early 1980s. The last mass immigration was related with war and political transformations in the countries of the former Yugoslavia and with revolutionary movements in the countries of North Africa. At the moment, the main cause of immigration to Switzerland is work, which - after bilateral agreements with European Union - attracts especially Germans.

Swiss multilingualism is an inevitable part of the Constitution. It guarantees that anyone in Switzerland, regardless of nationality, has the right to use their own language in both private and public

\footnotetext{
${ }^{1}$ Federal Statistical Office: https://www.bfs.admin.ch/bfs/de/home/statistiken/bevoelkerung/migrationintegration/auslaendische-bevoelkerung.html (accesed 09/01/2020).
} 
spheres. Nonetheless, this basic right is restricted by the obligation to use the official language in contacts of individuals with cantonal and federal authorities.

Another restriction concerns the territoriality principle, according to which different cantons have different official languages. However, considering the fact that multilingualism in Switzerland is accepted, the principle of linguistic territoriality raises more and more doubts and resistance from the new linguistic minorities (Müller/Scheffer, 2008: 297). Especially in comparison with the old language minorities (Italian and Romansh) the territorial principle seems to be hard to accept (Müller/Scheffer, 2008: 306).

The constitution of the Swiss Confederation has sufficient regulation to standardize this outdated process of language policy and allow new national minorities to benefit from the same basic rights as linguistic minorities which already are legally recognized in the Alpine country (Baumann/Stolz, 2007). However, there are no concrete and decisive legal regulations regarding this issue.

\section{Religious minorities}

The complications with process of unification of the Switzerland initiated at the beginnings of its statehood. The problems emerging from religious differences led to numerous wars and rebellions. A glaring example was the conflict between Catholics and Protestants in 1847, which led to the formation of the Swiss federal state in 1848.

Article 15 of the Swiss Constitution contains general laws that guarantee the freedom of religion.

[c] 1. Freedom of religion and conscience is guaranteed.

2. Every person has the right to choose freely their religion or their philosophical convictions, and to profess them alone or in community with others.

3. Every person has the right to join or to belong to a religious community, and to follow religious teachings.

4. No person may be forced to join or belong to a religious community, to participate in a religious act, or to follow religious teachings. [c/]

These rights, like any others, may be limited which is guaranteed by the Article 36 of the Swiss Constitution:

[c] 1. Restrictions on fundamental rights must have a legal basis. Significant restrictions must have their basis in a federal act. The foregoing does not apply in cases of serious and immediate danger where no other course of action is possible.

2. Restrictions on fundamental rights must be justified in the public interest or for the protection of the fundamental rights of others.

3. Any restrictions on fundamental rights must be proportionate.

4. The essence of fundamental rights is sacrosanct (Baumann/Stolz, 2007) [c/] 
In contradiction to Article 15 stands Article 72 paragraph 3, which prohibits the construction of minarets in Switzerland ${ }^{2}$. The Article 72 was changed after referendum in 2009. The Swiss society voted against the construction of towers on Muslim temples in the territory of the Helvetic state (Müller/Tanner, 2009:38.

Switzerland has no official state religion. Predominant religion is Christianity, the largest religious minorities is established by Islam. Historically the country was evenly balanced between Catholics and Protestants, with a complex patchwork of majorities over most of the country's territories. This confirms that Switzerland represents the classical form of a multicultural democratic state (Kymlicka, 2000).

Table 2. Division of Swiss society according to religion in 2013-2015 (\%)

\begin{tabular}{|l|l||}
\hline Religion/Church & $\mathbf{2 0 1 3 - 2 0 1 5}(\mathbf{\%})$ \\
\hline \hline Catholic Church & 37.9 \\
\hline Swiss Reformed Church & 25.5 \\
\hline Islam & 5.1 \\
\hline Orthodoxy & 2.3 \\
\hline New Apostolic Church & 0.3 \\
\hline Pietism & 0.6 \\
\hline Hinduism & 0.5 \\
\hline Buddhism & 0.5 \\
\hline Judaism & 0.2 \\
\hline Pentecostalism & 0.4 \\
\hline \hline Other christian religions & 0.6 \\
\hline Unaffilliated & 24.4 \\
\hline \hline Other & 1.9 \\
\hline
\end{tabular}

Source: Federal Statistical Office:

https://www.bfs.admin.ch/bfs/de/home/statistiken/bevoelkerung/sprachen-religionen/religionen.html $(08 / 01 / 2020)$

\footnotetext{
${ }^{2}$ Article 72 paragraph 3 in German: „Der Bau von Minaretten ist verboten”.
} 
Table 2 presents religious diversity among Swiss. The dominance of Christian churches is clear. Particular attention must be given to the high number of Muslim minority, and the small number of the followers of Judaism, which is related to the historical situation of the Switzerland.

The largest Christian denominations are Catholic Church (37.7\%) and Swiss Reformed Church (25.5\%). The bigger cities (Bern, Zurich, Basel, and Geneva) are Protestant, in central Switzerland and Ticino catholic religion is dominant. Immigration completes this picture with Islam, Orthodoxy and other significant religious minorities: Pietism, the New-Polish Church, Hinduism, Buddhism, Pentecostals, Jehovah's Witnesses and Judaism.

The Muslim community in Switzerland is the third largest religious group. The co-existence of Christians and Muslims requires solving of difficult integration problems, which come automatically when such different religions and cultures meet. It is not easy even in such a liberal and democratic country as Switzerland. The essential issue is the granting of rights to foreigners who are followers of non-Christian religions. The so called fundamental rights apply to every resident of the Alpine Republic (Kälin, 2000: 58).

Over $24 \%$ of the population have no religious affiliation. The surveys found that only $48 \%$ of Swiss believe in God (despite their religious affiliation), a further 39\% claims there is some sort of spirit or life force, and $9 \%$ declare atheism. The remaining $4 \%$ can not or do not want to define themself ${ }^{3}$.

In 1980 a referendum was held on the complete separation of church and state, however it was rejected ( $80 \%$ votes against).

Swiss Catholics in terms of religiosity do not differ from most European nations. In religious practices, mainly on the occasion of major ceremonies and the most important holidays, the participation of the congregation is limited to the minority. The papacy, Vatican centralism and dogmatism of the Church are subjected to very severe criticism not only by adherents of the Roman Catholic Church, but also by the Catholic hierarchy, which demands greater independence of Church in Switzerland. Most of the Catholic parishes in Switzerland are very liberal and egalitarian: the priests are changing the traditional liturgy. Mass can be celebrated by secular catechists and pastors or pastors from the Protestant church (Matyja, 2014). Generally in Switzerland there are not enough priests to evangelize; moreover, the number of priests is falling, due to the huge drop in the number of vocations. It leads to the situation in which numerous of parishes no longer have priests. Therefore, the rest of the priests have additional responsibilities, and fail to fulfill their priesthood duties outside the church. Consequently more and more priests immigrate to Switzerland from abroad (Matyja, 2014: 20).

\footnotetext{
${ }^{3}$ The data from The Swiss Federal Statistical Office: 2019
} 
The Protestant Reformation in Switzerland began in the sixteenth century, with a split into followers of Luther and supporters of Zwingli and Calvin. Currently, the Protestant church is identified with those Protestant communities that were officially recognized in 1648 as part of the peace treaty in Osnabrück (Porebski, 2011: 116).

Protestant churches in Switzerland adopted presbyterian-synodal model of church governance. Local communities do not recognize supreme authority, there is no hierarchy or pedagogical authorities. This means that the hierarchy is of an administrative and not spiritual nature. Members of the autonomous parishes choose their own authorities themselves, they also determine the amount of the church tax and manage their financial matters (Porebski, 2011:117).

The growth of the Muslim community in Switzerland is related with the economic migration and a large influx of refugees from the Third World and the countries of the former Yugoslavia. Twothirds of Muslims are Sunni Muslims, Shiites and Levites also create a significant group. Islamic organizations in Switzerland are very politically diverse and conflicted, therefore can not establish a leader that would represent the whole community and dialogue with federal or cantonal authorities. The Muslim law based on the God's will, also determines this negative phenomenon (Ruthven, 1998). This raises the problem of the relationship of Muslims to the secular state and its democratic form of government.

The most dynamic increase in the number of the faithful in the years 1980-2010 occurred in Muslim minority. Back in 1980, the number of Muslims in Switzerland was 56,000, in 2000 it reached about 310,000 in 2010: 350,000 and in 2015 it increased to about 500,000.

In different situation are the Swiss followers of Judaism. Their population is much lower than the number of Muslims (around 20,000-0.25\%).

The numbers of followers of other religions - both Christian and non-Christian - are minor and do not show any upward trends.

The phenomena mentioned above is typical not only for Switzerland, but also in other Western European countries.

To sum up, it must be stated that the religions: Catholic, Protestant and Islamic dominate in the Swiss society $(68.5 \%)$, with strong dynamic growth on the part of Islam.

\section{New cultural minorities}

The influx of new cultural minorities to Switzerland began after the Second World War and was directly connected with economic migration, with the large influx of gastarbeiters from southern European countries and refugees from the Third World and from the former Yugoslavia. In 1945 first immigrants from Turkey arrived in Switzerland. With the financial support from the state they were able to study at the Swiss universities. Most of them left Switzerland after graduation, however some stayed. 
In 1946 a group of Muslim missionaries came to Switzerland under the name Ahmadiyya, and built there the first mosque in 1963.

The mass immigration process in Switzerland can be divided into two main stages. The first stage is the period from the early 1960s to the mid-1970s, when Turkish, Italian, Spanish and Portuguese unskilled workers arrived in Switzerland. The flourishing economy needed new workforce (Behloui/Lathion, 2007: 198). At the same time, there was also an influx of migrant seasonal workers from Yugoslavia. This stage is called "immigration of man".

Later, temporary work and residence permits in Switzerland for migrant workers were changed into permanent residence, which was connected with the war in Bosnia and Kosovo.

In the 1990s families of the seasonal workers began arriving to Switzerland, which was the beginning of the second stage of the new mass migration process. The influx of women and children became a challenge for the Swiss state, characterized by the integration of Muslim women in the work process and children within their education (Kälin, 2000: 151-153) At this stage of Muslim immigration to Switzerland, for the first time the cultural clash between the Swiss society and the world of Islam took place. The immigrants had different views on the role of women and man in the families and society, different principles regarding upbringing children and attitude towards state institutions. The arriving Muslims started to fear of losing their religious and cultural values; therefore they began to form numerous languages, cultural and religious organizations.

After 2014 there was an influx of refugees from the northern African countries of Magreb, which was connected with revolutionary movements and civil wars in these countries. That resulted in waves of refugees from Central Africa and Asia fleeing to Europe, including Switzerland.

\section{Protection of national minorities}

International law includes the protection of national, yet not cultural minorities. In Switzerland the protection of national minorities is also based on international standards (Janusz, 2011). It should be mentioned that the Swiss political culture emphasizes the principle of proportionality and consensus in political representation, and applies it to political parties as well as national languages and religion. Switzerland does not have many conflicting or overlapping constitutional provisions, cantons and local communities. The local-political sense of belonging is very deeply rooted in the mentality of Swiss citizens, who identify themself with the community and the canton. They more likely consider Bern to be the seat of the government, not the capital of the country.

Compared with the constitution of 1848, and its modified form from 1874, the current preamble to the constitution is more specific and focuses essentially on the concept of "social diversity" and "social multiplicity", while previous versions of the constitution only emphasized the concept of "unity ". This difference is of great importance The statement of "unity in multiplicity" underlines the multicultural 
nature of the Helvetic state, at the same time suggesting the protection of national minorities (Tschannen, 2007).

How does the current constitution of the Swiss Confederation protect national minorities? The Constitution does not contain a definitive definition of the concept of "national minorities", which does not mean that these minorities are not protected. In Swiss society, as in any society hosting immigrants, there are conflicts between majority and minority groups and their cultures, which generate a fair interpretation of fundamental rights.

The preamble of the Swiss constitution enshrines the important role of multiculturalism in the Alpine country. It determines the will to live together with mutual respect, according to the "unity in multiplicity" concept:

[c] [...]resolved to renew their alliance so as to strengthen liberty, democracy, independence and peace in a spirit of solidarity and openness towards the world, determined to live together with mutual consideration and respect for their diversity, conscious of their common achievements and their responsibility towards future generations, and in the knowledge that only those who use their freedom remain free, and that the strength of a people is measured by the well-being of its weakest members, [...]. [c/]

The Article 2 paragraph 2 of the Constitution stipulates that:

[c] It shall promote the common welfare, sustainable development, internal cohesion and cultural diversity of the country [c/]

It underlines the unity of different cultures, with society forming a multicultural state, while its diversity should be seen as an opportunity, not as a threat (Linder/Zürcher, 2008: 211).

Are the above-mentioned fragments of the constitution sufficient to confirm the protection of national minorities within the Swiss political system? They are certainly insufficient and provoke not only a social discussion, but also a parliamentary debate. Both the parliament and the government, as the highest political instances in Switzerland, are obliged to interpret the constitution and fully define the objectives of protecting national minorities (Cattacin, 2003). Nevertheless, Article 2 paragraph 2, despite the very abstract description of minority protection, is the binding norm at the present time.

\section{Integration policy}

The formation of the federal state in 1848 allowed reaching the expectations of the linguistic and religious minorities, by leaving a generous share of self-determination to cantons (Manatschal, 2013). Today the Swiss political system is considered to be a model in the process of solving multicultural problems. However, not all national minorities can benefit from the positive features of the federal system (Cattacin/Famos/Duttwiler/Mahnig, 2003). A vivid example was the policy of the Swiss Confederation towards the Roma people, between 1930 and 1970 it led to the destruction of their 
nomadic lifestyle. Similarly, the Federal Council's policy concerning the new immigration began in the 1950s, can not be compared with the generous attitude of Helvetians towards traditional ethnic minorities.

The necessity for systematic integration policy in Switzerland appeared in the nineties of the twentieth century, after removing the anti-immigration tendencies and hostile attitude towards foreigners.

The current Swiss policy towards new national minorities was formulated in a government report on the Framework Convention for the Protection of National Minorities. The Swiss Confederation ratified this Convention in 1998 and formulated the definition of national minorities, adjusting it to the situation in the country.

According to the new definition national minorities in Switzerland are the groups of individuals who are numerically smaller than the rest of the population of the country or of a canton and who have Swiss citizenship. They should have longstanding and firm ties with Switzerland, at the same time a will to safeguard their national identity, in particular their tradition, their culture, their religion and their language (Milic, 2008).

The discussion about foreigners and new national minorities in Switzerland boils down to the idea of integration. Next to work, the principle theme is the knowledge of one of the four national languages in Switzerland, which is defined as the key to the full integration. The discussion atmosphere is similar to the debates in the European Union countries, although the additional aim is to find the best integration idea (Ridel, 2005). The integration process is unavoidable, because Switzerland's economy depends, to a large extent, on the flowing workforce. In the view of the importance of this process, it is surprising that Swiss legislation has only recently recognized integration as a responsibility of the State.

The system of direct democracy makes it difficult and time-consuming to ensure equality for cultural and national minorities in Switzerland (Matyja, 2016). The research of the National Research Program at the University of Bern has shown, that the referendums held in Switzerland over the last 120 years, reveal the negative attitude towards national minorities. Their equality reassurance was delayed, while the laws concerning granting the equal rights to minorities were tighten up. However, not only the instruments of direct democracy such as referendum and popular initiative negatively influenced the position of national minorities. An important role was and is still played by the state offices and political elites.

Although the political elites accept and recognize the rights of the national minorities, they do not introduce this problem in the parliament — due to the fear of a political fight in the event of a possible referendum (Gamble, 1997: 245-269). Additionally, the values and views represented by the society should be considered. Citizens in favor of open-to-the-outside Switzerland, are usually also supporters of the extension of rights for national minorities. Conservatives, on the other hand, try to limit these 
rights to a minimum, arguing this position with fear of social alienation and the loss of the Swiss national identity. The national minorities also have an impact on their position and chances of equality in the Swiss society. Minorities, who are unable to assimilate and represent foreign values, have very little chance to be accepted by the voters - they are themself closing the door on their integration process.

In the 19th century, mainly the Catholics and Jews were the victims of unfavourable votes in referendums (Krauthammer, 2000). In 1874, the rights of the Catholics were limited in the modified Constitution and it was not until 1973 when the ban on banished Jesuits was lifted on (Linder/Zürcher, 2008). The Jews were discriminated on the territory of Switzerland for a long time. In Constitution 1848 their rights to settle freely and their religious rights were limited. The equal rights were only granted with the revised constitution of 1874 (Külling, 1977).

In recent years, a blatant example of the negative impact of direct democracy on the equality of national minorities was the previously mentioned referendum on the construction of Muslim minarets in Switzerland.

Current integration instruments are insufficient and reach only some of those who need it. However, it seems necessary to reach all members of national minorities who do not use one of the official languages in Switzerland and does not belong to any religion recognized under public law. The fact of not knowing the official language should not be a reason of any discrimination.

\section{Direct democracy and the rights of cultural minorities}

Whether the Swiss federal system has more flaws or advantages considering national minorities, entails an ideological discussion, because there is no meaningful comparison with the political systems of other countries (Gabriel, 1997). Federalism in Switzerland has many determinants that — depending on the point of view and the situation - can be considered positive or negative, regarding the relationship of the Swiss state to national minorities (Christmann, 2010: 1-41).

Due to the multiculturalism it would be difficult to achieve a socio-political consensus without federalism (Matyja, 2001: 129-136). This system provides that old ethnic, linguistic or religious minorities do not feel disadvantaged or worse treated than the others. Numerous decisions are reached at the lowest political level, which protects the citizen against unreasonable or unintentional interference from the state (Eichenberger, 2002). Federalism suppresses intercultural and ethnic tensions and adjusts state activities to interregional differences. Minor regional tensions and insignificant political conflicts, are the best evidence that the Switzerland as a federal state functions optimally. Although the process of negotiation on the intercantonal and at the federation-cantonal level is often time-consuming, which can be incomprehensible, it ultimately leads to the positive and risk-free results.

On the other hand, representatives of the cultural minorities of one canton may feel harmed if they do not have the same rights as their counterparts in the neighboring canton (Donovan, 1999: 1010-1024). 
Cantonal competences and direct democracy are consistently defended in Switzerland, the intercantonal controversies are resolved in a peaceful way by agreements between cantons.

The Swiss political system differs remarkably from the other known democratic systems of the European countries. Through constitutional legislation, referendum and popular initiative, the nation has become a true sovereign with a voice in every important decision: from communal matters to imposing constitutional change. The collective system of power and a strong influences of interest groups and citizens can not be found in any other country. Therefore, the Swiss federalism, with its complexity and specificity, can not be directly transferred to another political system without prior thorough analysis of its genesis (Kirchgässner/Gebhard/Lars/Savioz, 1999).

Hence, a deep analysis of the functioning of national minorities in the Switzerland is possible only on the basis of examining the specificity of the political system of the Alpine Republic, which determines the existence of these minorities.

It is commonly known that there is a conflict of interest between democracy and state under the rule of law, and between majoritarian democratic politics and liberal principles. The conflict can be controlled; however it can not be resolved. The critics of the system of direct democracy make an assumption that majorities in a given society do not show in their behavior towards minorities either reasonableness or altruism, therefore, when they vote on issues concerning minorities they only follow the economic reasons (Feld/Savioz, 1997: 507-538).

Nevertheless, the results of referenda regarding cultural minorities in Switzerland between 1970 and 1996 shows that in 64 votes, up to $70 \%$ of the votes was in favor of the rights of minorities.

The relation between direct democracy and human rights is very ambivalent. The instruments of direct democracy give the majority the greater chances to move forward their propositions than they would have in representative political system (Matyja, 2009: 13). Direct democracy is much more responsive to the preferences of the society, in extreme cases people can even accept by voting a proposal which is against the rights of human and citizen.

In representative democracy the process of making political decisions is associated with the political debate, arguments, and above all with the formation of a coalition. The political discussion is also a part of a direct democracy, however there are no mechanisms filtering the political decisions before they are definitively approved by the society at the urn (Frey/Goette, 1998: 1343-1348).

At this point, the question should be asked whether all laws regarding minorities in a given state should be subject to voting? Or: what minority rights should be considered as fundamental and not subject to a public vote?

Searching for the answers to these questions, the importance of the constitution should be considered. It contains fundamental regulations protecting the rights of the linguistic and religious minorities (Richter, 
2005). Its proper interpretation and proper application in practice is the task of the Swiss government and administration.

\section{Conclusions}

The principle of the Swiss "unity in multiplicity" is best reflected in the multiculturalism and multilingualism of Switzerland, but also a relatively high percentage of the foreigners.

At present, there are four language groups in Switzerland (German, French, Italian and Romansh) and two significant religions (Catholic and Protestant).

In discussions held in the media and in the political arena, there is a definite concern about the unity of the Swiss people in the case of the increasing number of languages spoken by the people of that country. There is a risk of impoverishment of the cultural heritage and the weakening of the national identity.

The necessity for systematic integration policy in Switzerland appeared in the nineties of the twentieth century, after removing the anti-immigration tendencies and hostile attitude towards foreigners.

The current Swiss policy towards new national minorities was formulated in a government report on the Framework Convention for the Protection of National Minorities. The Swiss Confederation ratified this Convention in 1998 and formulated the definition of national minorities, adjusting it to the situation in the country.

The equal rights for cultural minorities in Switzerland apply not only to linguistic but also religious minorities. Current integration instruments are insufficient and reach only some of those who need it; however it is necessary to reach all members of cultural minorities.

The integration processes within the Confederation, where the constitution determines the relationship between the cantons and the state, played a fundamental role in creating the multicultural state and society. The Constitution does not contest the legal identity of the cantons and does not turn against regional culture and the local identity of the citizens.

Nowadays Switzerland similarly to modern Europe faces the necessity of answering to strategic civilization issues. One of the crucial problems is the future shape of this multicultural society with its whole mosaic of various minorities and national groups. On the one hand - what is particularly symptomatic of the most socially and economically developed countries in Europe - there is a visible growing demographic pressure of the immigrants, who preserve the awareness of their cultural separateness. The Swiss population, unlike the most modern European societies, have never been a homogeneous society in which internal integrity is created and strengthened by unified identity, history and culture. However, currently as a result of the emerging of new non-Christian minorities a significant 
increase in social tensions and changes in electoral attitudes and preferences can be noticed. This implies a clear renaissance of social support for the far-right parties.

On the other hand, the positive attitude towards integration processes declared in Switzerland, built on the basis of centuries-old tradition of tolerance for "others", clearly loses its strength in confrontation with the need to respond to the new and unknown issues.

It seems that the key to success is to cease the exaggeration of two significant myths. First of all, the break with the primacy of the Christian religion. Second, it seems necessary to modify the concept of the foreign policy in Switzerland. Progressive European integration, which also affects political and social life in Switzerland - regardless of the fact that the country does not belong to the European Union - generates the need for socio-political evolution also in the Alpine country and a new modus vivendi between the Swiss nation state and the Union. It is connected with transferring the responsibility for multicultural policy from regional level to the level of federation in the interest of efficient functioning of the Swiss state, according to the traditional Helvetic principle of "unity in multiplicity".

\section{References}

[1] Bakic N, Sprachliche Minderheiten in Serbien und in der Schweiz, Zürich 2010.

[2] Baumann M., Stolz J., Eine Schweiz - viele Religionen. Risiken und Chancen des Zusammenlebens, Bielefeld 2007.

[3] Behloui S.M., Lathion S., Muslime und Islam in der Schweiz: Viele Gesichter einer Weltreligion, Eine Schweiz - viele Religionen. Risiken und Chancen des Zusammenlebens, Hrsg. M. Baumann, J. Stolz, Bielefeld 2007.

[4] Bickel, Hans, Schläpfer, Robert (red.): Die viersprachige Schweiz, Aarau 2000.

[5] Büchi Chr., Röstigraben. Das Verhältnis zwischen deutscher und welscher Schweiz. Geschichte und Perspektiven, NZZ, Zürich 2000.

[6] Budyta-Budzynska M., Socjologia narodu i konfliktów etnicznych, Warszawa 2010.

[7] Bundeskanzlei, Bundesverfassung der Schweizerischen Eidgenossenschaft vom 29. Mai 1874, Bern 1998.

[8] Cattacin, Sandro, Famos, Cla Reto, Duttwiler, Michael, Mahnig, Hans: Staat und Religion in der Schweiz - Anerkennungskämpfe, Anerkennungsformen, Bern 2003.

[9] Christmann, Anna: Demoklesschwert Volksabstimmung? Genese von Anerkennungsregeln für Religionsgemeinschaften in den Schweizer Kantonen, w: Swiss Political Science Review, nr 2010/16 (1), s. 1-41.

[10] Donovan, Todd, Bowler: Direct Democracy and Minority Rights: An Extension, w: American Journal of Political Science, 1999/45, s. 1020-1024. 
[11] Eichenberger R., Starke Föderalismus. Drei Reformvorschläge für fruchtbaren Föderalismus, Orell Füssli, Zürich 2002.

[12] Feld, Lars P., Savioz, Marcel R.: Direct Democracy Matters for Economic Performance. An Empirical Investigation, w: Kyklos 1997/50, s. 507-538.

[13] Frey, Bruno, Goette, Lorenz: Does the Popular Vote Destroy Civil Rights? w: American Journal of Political Science, 1998/42, s. 1343-1348.

[14] Gabriel, Jörg Martin: Das politische System der Schweiz, Bern 1997.

[15] Gamble, Barbara: Putting Civil Rights to a Popular Vote, w: American Journal of Political Science, 1997/41, s. 245-269.

[16] Gellner E., Nations and Nationalism, Ithaca. Cornell University Press 1983.

[17] Grenzen des Zumutbaren. Erfahrungen mit der französischen Okkupation und der Helvetischen Republik (1798-1803), Hrsg. A. Würgler, Basel 2011.

[18] Haller, Walter: Schweizerisches Bundesstaatsrecht, 6. Auflage, Zürich/Basel/Genf 2005.

[19] Janusz G., Ochrona mniejszości narodowych w Europie, Lublin 2011.

[20] Kälin, Walter: Grundrechte im Kulturkonflikt: Freiheit und Gleichheit in der Einwanderungsgesellschaft, Zürich 2000.

[21] Kirchgässner G. et al., Die direkte Demokratie. Modern, erfolgreich, entwicklungs- und exportfähig, Helbing \& Lichtenhahn, Vahlen, Basel-Genf-München 1999.

[22] Krauthammer, Pascal: Das Schächtverbot in der Schweiz 1854-2000: Die Schächtfrage zwischen Tierschutz, Politik und Fremdenfeindlichkeit, Zürich 2000.

[23] Külling, Friedrich Traugott: Antisemitismus in der Schweiz zwischen 1866 und 1900, Zürich 1977.

[24] Kymlicka W., Multikulturalismus und Demokratie: über Minderheiten in Staaten und Nationen, Frankfurt am Main 2000.

[25] Linder W., Zürcher R., Bolliger Christian: Gespaltene Schweiz - geeinte Schweiz. Gesellschaftliche Spaltungen und Konkordanz bei den Volksabstimmungen seit 1874, Baden 2008.

[26] Manatschal A., Kantonale Integrationspolitik im Vergleich. Eine Untersuchung der Determinanten und Auswirkungen subnationaler Politikvielfalt, Nomos, Baden-Baden 2013.

[27] Matyja M, Federalism and multiethnicity in Switzerland, [w:] Essays on Regionalisation. Collection of reports submitted at the International Conference. Regionalisation in Southeast Europe. Comparative Analysis and Perspectives, ed. Agencija Lokalne Demokratije, Center Agency of Local Democracy, Subotica 2001, s. 129-136.

[28] Matyja M., Swiss Made. Jak funkcjonuje międzykulturowa Szwajcaria?, Poligraf, Brzezia Łąka 2010. 
[29] Matyja M., Besonderheiten des politischen Systems der Schweiz. Föderalismus und direkte Demokratie, „Europa Regionum” 2009, Bd. 12, s. 13-23.

[30] Matyja, M., Dysfunkcjonalnosc szwajcarskiej demokracji bezposredniej, Adam Marszalek Torun 2016.

[31] Matyja, M., Granice demokracji bezpośredniej. Wplyw szwajcarskiego systemu politycznego na proces integracyjny muzulmanskiej mniejszości religijnej, Poligraf, Brzezia Łąka 2014.

[32] Milic, Thomas: Ideologie und Stimmverhalten, Zürich 2008.

[33] Müller F., Tanner M., Muslime, Minarette und die Minarett-Initiative in der Schweiz. Grundlagen, [w:] Streit um das Minarett. Zusammenleben in der religiös pluralistischen Gesellschaft, Hrsg. M. Tanner et al., Zürich 2009.

[34] Müller J.P., Schefer M., Grundrechte in der Schweiz. Im Rahmen der Bundesverfassung, der EMRK und der UNO-Pakte, Bern 2008.

[35] Porebski A., Wielokulturowosc Szwajcarii na rozdrozu, Krakow 2009.

[36] Richter, D., Sprachenordnung und Minderheitenschutz im schweizerischen Bundesstaat: Relativität des Sprachenrechts und Sicherung des Sprachfriedens, Springer 2005.

[37] Riedel, Sabine, Muslime in der Europäischen Union. Nationale Integrationskonzepte im Vergleich, Berlin 2005.

[38] Ruthven M., Islam, przeł. K. Pachniak, Warszawa 1998.

[39] Tschannen, Pierre: Staatsrecht der Schweizerischen Eidgenossenschaft, Bern 2007.

[40] Vatter, Adrian: Vom Schächt-zum Minarettverbot, Zürich 2011.

[41] Wojtowicz J., Historia Szwajcarii, Wrocław-Warszawa-Kraków-Gdańsk-Łódź 1989.

[42] Departament ds. Statystyki Konfedertacji Szwajcarskiej:

https://www.bfs.admin.ch/bfs/de/home/statistiken/bevoelkerung/sprachenreligionen/sprachen.assetdetail.2244919.html (dostep z 11.04.2018)

[43] Departament ds. Statystyki Konfedertacji Szwajcarskiej: https://www.bfs.admin.ch/bfs/de/home/statistiken/bevoelkerung/sprachenreligionen/religionen.html (dostep z 19.04.2018)

[44] Zbinden R., Wielokulturowość w Szwajcarii, thumaczenie M. Tarasińska, 2006: http://www.tolerancja.pl/?wielokulturowa-szwajcaria,319,,,2 (2.05.2018). 